\title{
Patients' Rights: Awareness of the Pediatric Patients' Guardians Attending Benha University Hospital.
}

\author{
Rasha SH Eldesouky ${ }^{*}$, Mohammed M El Bakry ${ }^{* *}$, Hesham A El Ghaiaty ${ }^{* *}$ and Azza F \\ $\mathrm{Ata}^{* *}$. \\ *Department of Community Medicine, **Department of Pediatrics. \\ Faculty of Medicine, Benha University, Benha, Egypt.
}

\begin{abstract}
Introduction: The majority of the patients would do nothing when facing problems or harm in the hospital if they ignore their rights or how to insist on them. Objectives: The objectives of this cross sectional study were to assess the awareness of the pediatric patients' guardians about Patients' Rights and to detect the factors associated with this awareness. Subjects and Methods: An interview questionnaire sheet was completed by 375 guardians; it included items about their socio-demographic characters and items to assess their awareness about the term of Patients' Rights and its components. Results: About $75 \%$ of the interviewed child guardians were familiar with the term of patient's rights, but only $4.8 \%$ of them reported they saw a post showing the patients' rights in the hospital. The guardians showed high awareness regarding some rights rather than others. Urban residents were significantly $(\mathrm{P}<0.05)$ more aware of two rights than rural ones. There was a significant association between the age of the sick child and the awareness of his guardian about another two rights $\mathrm{P}$ $(<0.05)$. Being familiar with the term of "Patients' Rights" and most of its components increased significantly $(\mathrm{P}<0.05)$ with higher educational levels of the guardians. Guardians of children with chronic diseases were significantly more familiar with the term $(\mathrm{P}=0.004)$. Conclusion: Although a good percentage of the studied guardians were familiar with the term of patients' rights, about one quartet of them did not know that their sick children have rights.
\end{abstract}

Key words: Patients' Rights, awareness, pediatric patients, guardians.

\section{Introduction}

Since the Human Rights issue has been introduced by the United Nations in 1948, the World Health Organization (WHO) generated Patient Bills of Rights (PBR), and legislations on PBR have been passed all over the world ${ }^{(1,2)}$. The notion of patient rights has been developed on the basis of concept of the person, and the fundamental dignity and equality of all human beings recognized in the Universal Declaration of Human Rights ${ }^{(3)}$.
The PBR are listed regulations for those receiving medical care (2) emphasizing on their care and treatment rights ${ }^{(4)}$. The majority of patients are not aware of their rights. Many patients simply do what the physician tells them to do. Some patients do not even ask why. Many patients do not ask questions because they do not want to take up the doctor's or nurse's time or appear ignorant. Some may not know which questions to ask ${ }^{(5)}$. 
The PBR are guarantees to ensure the ethical treatment of all patients, to help patients trust the healthcare system, to ensure that the healthcare system is fair and it works to meet patients' needs, to encourage patients to take an active role in staying or getting healthy, to stress the importance of a positive communication between patients and their healthcare givers, and to assure the provision of high quality healthcare $(2,6,7,8)$. Patients' rights observance is one of the effective measures of patients' satisfaction of health care services ${ }^{(9)}$.

Nowadays, healthcare systems in many countries have defined certain rights for patients, and the healthcare providers are obligated to abide by these rights when providing service (10). Patient's rights vary in different countries often depending upon the prevailing cultural and social norms but there is growing international consensus that they include privacy, confidentiality of medical information, treatment refusal, proper information on healthcare services, consultation on medical emergencies, and acknowledgment of relevant risk of medical procedures ${ }^{(1,2,4)}$. They may take the form of a law or a non-binding declaration $^{(2,6)}$.

In Egypt, in November 2003, the Doctors' Syndicate gave its overwhelming approval and support to the "Bill of Patients' Rights" recently issued by the New Kasr Al-Aini Teaching Hospital. The syndicate's council called for the document to be used as a "model" in all Egyptian hospitals. Although the bill is not binding, it is meant to protect patients' rights regarding the medical care and services they receive in the hospital's in- and out- patient clinics and emergency units ${ }^{(9)}$.
During the past few years, Egypt has implemented several diverse legal, political, and administrative mechanisms to deal with health care ethical problems. Despite major achievements, several problems persist, including unethical behavior of health care workers, inequity, and poor patient realization of selfempowerment ${ }^{(11)}$.

\section{Objectives}

The objectives of this work were: to assess the awareness about the patients' rights among the pediatric patients' guardians attending Benha University Hospital in Egypt and to detect the factors associated with this awareness.

\section{Methodology}

This was a cross sectional study, conducted upon the pediatric patients' guardians at the Pediatric inpatient wards, Pediatric outpatient clinic and the Emergency Room (ER) in Benha University Hospital. The field work was conducted over a period of three months, from the beginning of August till the end of October, 2013.

\section{Sample}

The required sample size was calculated according to the equation: $\mathrm{n}=\mathrm{Z}^{2}\left(\mathrm{p}^{*} \mathrm{q}\right) / \mathrm{E}^{2}$, where $\mathrm{n}=$ minimal sample size, $p=$ proportion of the guardians that are aware of the term of patient's rights (obtained from previous literature), it was $0.586^{(12)}$, $\mathrm{q}=(1-\mathrm{p}), \mathrm{E}=$ Standard error $=0.05$, so (n) was 373.

Data were collected from patients and their guardians attending the ER, the Pediatric outpatient clinic and the Pediatric inpatient wards over a period of three months, one month from each site. A structured anonymous 
questionnaire sheet was used; the total number of the guardians who accepted to participate was 375 out of 404 with $92.8 \%$ response rate.

The ER was visited twice weekly where the pediatric patients only were selected; the average number of the questionnaires filled each time was about 10 , the total number was 76 . The outpatient clinic was visited also twice weekly, the mean number of the patients' guardians who filled the questionnaire each time was about 19, the total number was 155 .The inpatient wards were visited once per week (to give chance for turnover), each time all patients in each ward were listed and given numbers, systematic random sample technique was used to select the patient where the first number was chosen by the simple random sample then each forth patient was taken, the total number was 144 .

\section{Tool of data collection:}

A structured anonymous interview questionnaire sheet written in Arabic language and containing 2 sections was used:

1- Section 1: The socio-demographic data of the children and their guardians.

2- Section 2: Assessed the familiarity of the patients' guardians with the term of "Patients' Rights" and evaluated their awareness about fourteen Patients' Rights, it also investigated the presence of a chart of Patients' Rights in the hospital. This part was adopted and modified from the list of New Kasr Al-Aini Teaching Hospital and similar study ${ }^{(12)}$. Two academic Public Health professors have revised the questionnaire for its content and construct validity.

\section{Ethical considerations:}

A written informed consent (in Arabic language) was obtained from the patients' guardians before participation; it included data about aim of the work, study design, site, time, subject and tool. They were informed that all collected data will be confidential and used for scientific purposes only. They were informed also that no invasive or painful techniques will be carried upon them. Also, an approval from The Research Ethics Committee in Benha faculty of medicine was obtained before the conduction of this work, and lastly an official permission was obtained to interview the patients and their guardians from the Dean of the Faculty of Medicine and the Head of the Pediatrics Department.

\section{Statistical analysis:}

The collected data were tabulated and analyzed using SPSS version 16 software. Qualitative data were expressed as frequencies and percentages, while continuous variables were presented as mean \pm standard deviation and range. Chi

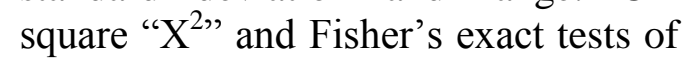
significance were used. Monte Carlo Exact Test was used to calculate Fisher's exact test for tables larger than $2 \times 2$. The accepted level of significance in this work was 0.05 ( 2 sided $P$ value $\leq 0.05$ was considered significant).

\section{Results}

This study showed that the mean age of the studied children was 25.7 month (SD: 26.3). One hundred ninety seven $(52.5 \%)$ of the patients were males while $178(47.5 \%)$ were females,(75.5) were from rural areas. The interviewed person was mostly the mother $(91.2 \%)$. The age of the studied guardians ranged from 27 to 49 years with mean value $37 \pm 7.4,46.7 \%$ of them education level less than secondary school (Table 1). 
Table (2) shows that $20.8 \%$ of the studied sample were interviewed at the ER, 38.4\% were inpatients and $41.3 \%$ were seen at the outpatient clinic. It also shows that the majority of the illness was chest infections $(48.3 \%)$.Sixty point five percent of the illness were of acute condition and (39.2\%) were of chronic ones.

Table (3) shows that $74.9 \%$ of the interviewed child guardians were familiar with the term of patient's rights, $4.8 \%$ reported that they saw a post showing the patients' rights in the hospital, $(5.2 \%$ of those who at least read and write). More than half $(58.7 \%)$ of them didn't know that the physician should present himself to the patient, $24.8 \%$ did not know that the physician should tell the patient different ways of treatment, $38.4 \%$ were not aware of the right to obtain a copy of their child file, $30.1 \%$ did not know about the right of optional participation in research and $27.7 \%$ weren't aware about being transferred only after the availability of places and medical care. On the other hand, $89.3 \%$ of the child guardians were aware that the physician should respect the privacy of the patient and give him a chance to explain his complaint, $86.7 \%$ knew that the physician should explain the patient condition in an easy language and their informed consent should be taken before any intervention. Eighty nine point nine percent knew that the physician should deal with the patient in a good manner, $81.3 \%$ were aware of the right of confidentiality of the patient condition, $85.3 \%$ were aware that they should know the cost of treatment. Eighty two point one percent knew the right of having an emergency care before paying first, $80.5 \%$ knew the right to complain for any problem to the manager, and $86.4 \%$ of them were aware about the right to have a discharge summary.

The study investigated the relation between the awareness of the child guardians about patients' rights and the socio-demographic characteristics. The results showed that there was no statistically significant difference between gender of the child and the awareness of his guardians about his rights as a patient ( $\mathrm{P}$ value $>0.05$ for all rights).

Regarding residence, this work demonstrated that there was a statistically significant association between the awareness of the child guardian about the patient's rights and their residence regarding two Rights only; to obtain a copy of the patient's file $(\mathrm{P}=0.04)$ and the right for emergency care without paying first $(\mathrm{P}=0.01)$ where urban residents were more aware $(70.7 \%$ and $91.3 \%$ respectively) than rural ones $(58.7 \%$ and $79.1 \%$ respectively), (Table 4$)$.

This study revealed a significant association between the age of the sick child and the awareness of his guardian about two of the studied patient's rights, where the guardians of older children ( 5 to $<8$ years and $\geq 8$ years) were aware that the physician should presents himself to the patient at higher percentages $(76.9 \%$ and $55.2 \%$ respectively) than the guardians of the children aged 2 to <5years and those aged $<2$ years $(41.1 \%$ and $37.6 \%$ respectively) ( $\mathrm{P}=0.02)$. On the other hand, the guardians of the children aged $>8$ years were aware of the Right of optional participation in research at a lower percentage $(38.5 \%)$ than those of younger children aged $<2$ years, 2 to $<5$ years and those 5 to $<8$ years $(68.3 \%, \quad 74.1 \%$ and $79.3 \%$ respectively) $(\mathrm{P}=0.04)$, (Table 5). 
Table (6) shows that the percentages of being familiar with the term of "patients' rights" increased significantly $(\mathrm{P}<0.001)$ with higher educational levels of the guardians $(70.8 \%, 82.6 \%$ and $97 \%$ for basic, secondary and university level respectively) compared with illiterates $(42.2 \%)$. Also, the percentages of awareness of patients' rights associated with higher levels of guardians' education, this association was statistically significant $(\mathrm{P}<0.05)$ for all the studied patients' rights except the rights; " to be told about different treatment options", "optional participation in research" and "the referral protocols".

The results also demonstrated that guardians of children with chronic diseases were familiar with patients' rights at higher percentage $(83 \%)$ than those of children with acute medical conditions $(69.6 \%)$, this difference was statistically significant $(\mathrm{P}=0.004)$. On the other hand, there was no statistically significant association between the disease condition of the child and the awareness of his guardians with all patients' rights ( $\mathrm{P}>0.05$ for all).

It was found that $89.5 \%$ of the interviewed guardians at ER and $84.7 \%$ of those interviewed at the inpatient wards were aware of the right of having emergency care before paying first, compared with $76.1 \%$ of those seen at the outpatient clinics $(\mathrm{P}=0.03)$. Guardians interviewed at the inpatient wards were aware of the right of obtaining a copy of their files at higher percentage $(71.5 \%)$ than those seen at the ER and the outpatient clinics $(56.6 \%$ and $54.8 \%$ respectively), this difference was also statistically significant $(\mathrm{P}=0.007)$.

\section{Discussion}

The present study aimed to assess the awareness of patients' guardians about the term "patients' rights" and its different components. Such awareness carries an importance for the patients because if the guardians are aware of these rights during the course of medical care, they can preserve their children and be able to take the right decisions about their health status. Moreover, the majority of the patients and their guardians would do nothing when facing problems or harm in the hospital if they ignore their rights or how to insist on them ${ }^{(2)}$.

The present study showed that $74.9 \%(281 / 375)$ of the child guardians were familiar with the term of "patients' rights". On the other hand, $25.1 \%(94 / 375)$ of them did not know that their children have rights. The discrepancy between the relatively good level of the awareness about this term compared to the reasonable percentages of illiteracy and low educational levels among the studied child guardians could be explained by the figures of the source of their knowledge; where the majority $78.6 \%$ $(221 / 281)$ of the aware guardians heard about it from mass media as TV and Radio and community leaders (nurses). Sixteen point seven percent (47/281) obtained their information by attending health education sessions while only $4.6 \%(13 / 281)$ of them have read about it. It is clear that an important source of information is people who talk, where most illiterates can form an idea or take an experience especially if these people have the ability to explain ideas and persuade others by their thoughts. Moreover, guardians may show high percentage of yes when asked about the term, but give lower responses when asked about its components.

However, similar results were obtained by Ducinskiene et al., in $2006^{(13)}$ who conducted a cross 
sectional study in Lithuania to assess the awareness and practice of patient's rights law. They declared that $56 \%$ of the respondents were aware about the patients' rights of whom $19.8 \%$ read about them and $36.2 \%$ heard about them. This similarity could be due to similar socio-demographic conditions in poor developing countries. Also, a study carried out by Al Moajel, 2012 (14) to assess the hospitalized patients' awareness of their rights in Saudi governmental hospital, found that $25.2 \%$ of the studied patients don't know that they have rights. On the other hand, a hospital survey about patients' rights was tailored in South Egypt by Abou Zeina et al., $2013^{(11)}$. They declared that three quarters of the patients and their guardians did not know about the term of patients' rights. This is an alarm to give more attention to this region.

A small percent $(4.8 \%)$ of the studied guardians reported they saw a poster showing the patients' rights in the hospital, this may be due to choosing inaccessible places for the poster, the high percent of illiterate guardians who are not aware what posters illustrate or due to the absence of the poster. The investigator looked for such a poster in the Pediatrics department but it was absent, so, this percent reported by the guardians indicates seeing the post in other departments to which they were previously admitted.

The current work demonstrated that patients' guardians had high awareness regarding some rights rather than others. The reason for this may be that some rights are embedded in the treatment process so the guardians are fully aware of them. In this study, more than half $(58.7 \%)$ of the guardians didn't know that the physician should present himself to the patient. Similar findings were obtained by Habib and Al Siber,2013 ${ }^{(15)}$, they assessed the awareness and source of information of Patient's Rights through a cross-sectional survey in Riyadh Saudi Arabia. They stated that only $2.7 \%$ were aware about the right to have the health care staff introduce themselves to them. Yaghobian et al ,2014 ${ }^{(16)}$ declared that $63.4 \%$ of the participants in their study about the association between awareness of patient rights and patient's education, seeing bill and age, were not aware of the right to know the name of physicians and nurses. Patients didn't request to know healthcare providers, as they were afraid of receiving negative reactions. Health care providers should respect this right if they want a better communication with patients.

Thirty eight point four percent were not aware of the right to obtain a copy of their child file, this is much higher than the result obtained by Abd El Fattah et al, (2012) (12) who conducted a cross sectional study to assess the Awareness of Patients' Rights by Patients and Medical Staff in Some Pediatric Health Facilities in Ain Shams University Hospital, Egypt. They said that only $14 \%$ of their participant did not know about this right. $30.1 \%$ did not know about the right of optional participation in research and this is much lower than the figure declared by ${ }^{(14,15)}$ where $70.6 \%$ and $61.4 \%$ respectively reported they are not aware about this right. $27.7 \%$ weren't aware about being transferred only after the availability of places and medical care. The current results are lower than other results in previous literature as Parsapoor, et al., $2012^{(17)}$ who studied the views of patients, nurses and physician regarding patient's rights in three hospitals in Tehran; a general teaching hospital, a private hospital, and a 
public one, where the observance of the right to obtain a copy of their medical record was mentioned only by $70 \%$ of the participants.

Although this work demonstrated that $75.5 \%$ of the child guardians were aware that the physician should tell the patient different ways of treatment, and this figure is higher than those declared in literature ${ }^{(15,16)}$, there was still about quarter $(24.5 \%)$ of them ignoring this important item that is directly related to the treatment process and outcome.

On the other side, the results showed that guardians have had good awareness regarding some rights; $89.3 \%$ of them were aware that the physician should respect the privacy of the patient. Similar figures were obtained by previous studies (14, 15), where $85.0 \%$ and $80.3 \%$ of the patients respectively were aware about this right. $89.3 \%$ of them knew that the physician should give the patient a chance to explain his complaint .This figure is smaller than that obtained by (12), who found that $99.8 \%$ of the studied guardians were aware about this right. Regarding the right that the physician should explain the patient condition in an easy language, this work showed that $86.7 \%$ of the guardians were aware, this is higher than the results of a study carried out in Saudi Arabia ${ }^{(14)}$ where only $26.1 \%$ were aware and $10.5 \%$ were aware to some extent about this right. This difference is due to that the later study was conducted upon adult patients while the current work assessed the awareness of the pediatric patients' guardians where child caregivers are usually anxious and worry about their children's condition which is a motive to read and/or ask about their rights and duties especially in chronic conditions.
$89.9 \%$ of the child guardians were aware that the physician should deal in a good manner with the patient (receiving respectful and nondiscriminatory services regarding race, religion or political believes).This figure is similar to that obtained by previous investigator ${ }^{(14)}$. It also agrees with ${ }^{(17)}$, whose results demonstrated that there was a general consensus among patients regarding complete observance of the right of receiving respectful and non discriminatory service. In Turkey, a study by Kuzu et al ,2006 (18) upon 166 patients in internal medicine and surgery wards of three general hospitals in Denizly, showed that $91 \%$ believed that there were no fair accesses to healthcare services. It needs to be mentioned that the difference in terms of fair access to healthcare services may be due to different perceptions of the interviewees regarding the concept of fairness and justice.

Informed consent is an autonomous action by a subject or patient that authorizes a professional either to involve the subject in research or to initiate a medical plan for the patient ${ }^{(19)}$. The study revealed that $86.7 \%$ of the guardians knew that they should give an informed consent before any medical intervention. This finding is higher than that concluded by Kagoya et al., $2013^{(20)}$ in a study carried to assess the awareness of, responsiveness to and practice of patient's rights at Uganda's national referral hospital, where $73.5 \%$ of the patients were aware about this right. As regard confidentiality of the patient condition, about $81.3 \%$ of the studied sample was aware of this right. This agrees with ${ }^{(14)}$ where $80.3 \%$ of their participants were aware of this right, but it is lower than the findings obtained by ${ }^{(20)}$, where $94.8 \%$ of the patients knew it. 
Eighty five point three percent and $82.1 \%$ of the patients' guardians were aware that they have the rights to know the cost of treatment and to have an access to the emergency care before paying first respectively, these results are consistent with similar local study (12) where $79.9 \%$ and $86.3 \%$ of their studied patients were aware of these rights respectively. Considering the patient's right to complain to the manager for any problem, $80.5 \%$ of the studied guardians were aware about this right which is little higher than the figure declared by ${ }^{(15)}$ where $73.6 \%$ of their studied sample were aware of this right. The right of the patient to have a discharge summary was known by $86.4 \%$ of the guardians, which is higher than the result obtained by ${ }^{(14)}$ where $53.2 \%$ of the participants were aware about this right.

The results investigated the impact of the socio-demographic characters of the studied children and their guardians on the awareness of their guardians about patients' rights. It was shown that there was no statistically significant difference between gender of the child and the knowledge of his guardians about his rights as a patient; this is a good indicator that the culture of gender discrimination is not prevalent among the studied sample in spite of the high percentage of the illiterates and those of lower educational level. On the contrary, there was a significant association between the age of the sick child and the knowledge of his guardian about two of the studied patient's rights, where the guardians of older children were more aware that the physician should present himself to the patient. This can be explained on the basis of accumulation of knowledge and experience with increased child ages especially those suffering chronic conditions. On the other hand, the guardians of the children aged $>8$ years were aware of the Right of optional participation in research at a lower percentage than those of younger children, this is because this right is a specific and more scientific than other rights, not related to general knowledge, it depends on high educational level and culture, not only the time for accumulation of experience, so younger children may have highly educated and more cultured guardians than older ones.

The urban residents were more aware than rural ones regarding two Rights; to obtain a copy of the patient's file and the right for emergency care before paying first. This may be explained by the fact that general knowledge and access to information are higher among urban people that can improve their awareness of their rights. These findings agree with (2) who found a significant relationship between patient's awareness and the place of residency $(\mathrm{P}<0.001)$.

Being familiar with the term of patients' rights and most of its components significantly related to higher educational levels of the guardian. This result agrees with previously mentioned studies ${ }^{(2,13)}$ and with Zulfikar and Ulusoy, 2001 $1^{(21)}$ who carried out a Turkish study titled: Are patients aware of their rights? They stated that only $23 \%$ of patients were able to recognize their rights and this showed a significant difference related to the educational level. Moreover, guardians of children with chronic diseases were familiar with patients' rights at higher percentage than those of children with acute medical conditions, this is due to that chronic conditions may be a motive for the caregivers to read more or search more about such lifelong condition and the medical care that should be 
provided to their children, also, due to the accumulation of knowledge with the long duration of suffering.

\section{Conclusion}

This study tried to stand on the actual perception of our pediatric patients' guardians about the rights of their sick children and to highlight patients as a corner stone for improving the health care services depending on their expectations from the health institution. Although a good percentage of the studied guardians were familiar with the term of patients' rights, about one quartet of them did not know that their sick children have rights. On studying the rights individually, the results demonstrated that patients' guardians had high awareness regarding some rights rather than others. Moreover, some of them were aware of the rights but ignoring the term itself.

\section{Recommendations}

Increasing public awareness about patients' rights by some ways to as having a statement of patients' rights visibly displayed not only in the Pediatrics Department in Benha University Hospital, but in all public health institutions. Ideally, a completed list should be given to each patient and posted in each hospital room, unit, clinic, outpatient setting and physicians' office. At the same time, health care providers must fulfill their obligation to inform communities about patients' rights, and create mechanisms of grievance within public health institutions.

\section{References}

1) World Health Organization (WHO). Patient rights [internet]. [cited 2013 December 15]. Available from: http://www.who.int/ genomics/public/patientrights/en/

2) Mastaneh Z, Mouseli L. Patients' Awareness of Their Rights: Insight from a Developing Country. Int $J$ Health Policy Manag 2013; 1:1436. doi: 10.15171/ijhpm.2013.26

3) Välimäki M, Kuosmanen L, Kärkkäinend J, and Kjervike D. K. Patients' rights to complain in Finnish psychiatric care: An overview. International Journal of Law and Psychiatry 2009; 32 (3), 184-188.

4) Tabei SZ, Azar MR, Mahmoodian F, Mohammadi N, Farhadpour H, Ghahramani Y, et al. Investigation of the Awareness of the Students of Shiraz Dental School Concerning the Patients' Rights and the Principles of Ethics in Dentistry. $J$ Dent Shiraz Univ Med Scien 2013; 14: $20-4$.

5) Miracle V. Rights of Patients. Dimensions of Critical Care Nursing, AMJ, 2004; 23(3):129130.

6) Hakan O, Ozgür C, Ergönen AA, Onder M, Meral D. Midwives and nurses awareness of patients' rights. Midwifery 2009; 25: 75665. doi: 10.1016/j.midw.2008.01.010

7) Ghodsi Z, Hojjatoleslami S. Knowledge of students about Patient Rights and its relationship with some factors in Iran. Procedia - Social and Behavioral Sciences 2012; 31:345. doi: 10.1016/j. sbspro.2011.12.065.

8) Alghanim SA. Assessing knowledge of the patient bill of rights in central Saudi Arabia: a survey of primary health care providers and recipients. Ann Saudi Med 2012; 32: 151-5.

9) Elsayed KA, El-Melegy OA and El-Zeftawy AM. The Effect of an Educational Intervention on 
Nurses' Awareness about Patients' Rights in Tanta, Journal of American Science 2013;9(9):210219.

10) Joolaee $S$, Tschudin $V$, Nikbakht-Nasrabadi A, and Parsa-Yekta Z. Factors affecting patients' rights practice: the lived experiences of Iranian nurses and physicians. Int Nurs Rev 2008; 55(1), 55-61.

11) Abou Zeina HA, El NoumanAA and Zayed MA. Patients' Rights: A Hospital Survey in South Egypt, Journal of Empirical Research on Human Research Ethics 2013 ; 8 (3): 46-52.

12) Abd El Fattah FM . Awareness of patient's rights by patients and medical staff in some pediatric health facilities in Ain Shams University Hospital of pediatrics 2012, M.S.C. thesis ,faculty of medicine, Ain Shams University.

13) Ducinskiene D, Vladickiene J, Kalediene $\mathbf{R}$, and Haapala $I$. Awareness and practice of patient's rights law in Lithuania. $B M C$ International Health and Human Rights 2006; 6:10.

14) Al Moajel A. Hospitalized patients Awareness of Their Rights in Saudi Governmental Hospital. MiddleEast Journal of Scientific Research 2012; 11(3):329-335.

15) Habib F, and Al Siber $H$. Assessment of Awareness and Source of information of Patient's
Rights:a cross-sectional Survey in Riyadh Saudi Arabia. American Journal of Research Communication 2013; 1(2): 1-9 .

16) Yaghobian $M$, Kaheni $S$, Danesh $M$ and Abhari F.R. Association between awareness of patient rights and patient's education, seeing bill and age:Across-sectional study. Global journal of health science 2014; 6 (3):55-64.

17) Parsapoor A, Mohammed $K$, Malek Afzali, Ala'eddini $F$ and Larijani B. Observance of patient's rights :A survey on the views of patients,nurses and physicians. J Med Ethics Hist Med. 2012; 5: 5.

18) Kuzu N, Ergin A, Zencir $M$. Patient's awareness of their rights in developing countries .Public health 2006;120 (4):290-6.

19) Bhurgri $H$ and Qidwai $W$. Awareness of the Process of Informed Consent among Family Practice Patients in Karachi. JPMA 2004; 54(7):398-401.

20) Kagoya H.R, Kibuule D, Mitonga K.H ,Ekirapa-kiracho E and Ssempebwa J.C. Awareness of ,responsiveness to and practice of patient's rights at Uganda's national referral hospital .Afr J prm Health care fam Med. 2013 ;5 (1):142-48.

21) Zulfikar F and Ulusoy MF. Are patients aware of their rights? Nursing ethics 2001;8:487-498. 
Table (1): Socio-demographic characteristics of the studied patients and their guardians.

\begin{tabular}{|l|l|c|}
\hline \multicolumn{2}{|l|}{ Variable } & $\begin{array}{c}\text { N=375 } \\
\text { No. (\%) }\end{array}$ \\
\hline \multirow{2}{*}{ Sex } & Male & $197(52.5)$ \\
& Female & $178(47.5)$ \\
\hline Age (months) & Mean \pm SD; (range) & $25.7 \pm 26.3 ;(1 \mathrm{~m}-13 \mathrm{y})$ \\
\hline \multirow{2}{*}{ Residence } & Rural & $283(75.5)$ \\
\hline \multirow{2}{*}{ Guardians } & Urban & $92(24.5)$ \\
\hline Age of the guardians $(\mathbf{y})$ & Mean \pm SD; (range) & $342(91.2)$ \\
& Mother & $13(3.5)$ \\
\hline \multirow{2}{*}{ Education level of the } & Father & $37 \pm 7.4 ;(27-49)$ \\
guardians & Read and write & $30(8.0)$ \\
& Primary & $15(4.0)$ \\
& Prep. & $40(10.7)$ \\
& Secondary & $90(24.0)$ \\
& University & $167(44.5)$ \\
& Others $\dagger$ & $33(8.8)$ \\
\hline
\end{tabular}

$\dagger$ Others (Grandma - Sister - Aunt) 
Table (2 ): Frequency distribution of the studied patients according to the site of meeting and their illness.

\begin{tabular}{|c|c|c|}
\hline \multicolumn{2}{|l|}{ Variable } & $\begin{array}{c}\mathrm{N}=375 \\
\text { No. }(\%)\end{array}$ \\
\hline Site of meeting & $\begin{array}{l}\text { Emergency Room } \\
\text { Inpatient } \\
\text { Outpatient }\end{array}$ & $\begin{array}{l}76(20.8) \\
144(38.4) \\
155(41.3)\end{array}$ \\
\hline Disease & $\begin{array}{l}\text { Gastroenteritis } \\
\text { Chest infection } \\
\text { Inborn error of metabolism } \\
\text { Cardiology } \\
\text { Endocrinal diseases } \\
\text { Blood disorders } \\
\text { Genetic disorders } \\
\text { Failure to thrive } \\
\text { Renal diseases } \\
\text { Hepatic diseases } \\
\text { Neurological diseases } \\
\text { Typhoid fever }\end{array}$ & $\begin{array}{c}77(20.5) \\
181(48.3) \\
6(1.6) \\
5(1.3) \\
3(0.8) \\
20(5.3) \\
6(1.6) \\
21(5.6) \\
21(5.6) \\
10(2.7) \\
16(4.3) \\
9(2.4) \\
\end{array}$ \\
\hline Condition & $\begin{array}{l}\text { Acute } \\
\text { Chronic } \\
\text { Missing }\end{array}$ & $\begin{array}{c}227(60.5) \\
147(39.2) \\
1(0.3)\end{array}$ \\
\hline
\end{tabular}


Table (3): Frequency distribution of the studied sample according to the awareness of the child guardians about the patients' rights.

\begin{tabular}{|c|c|c|}
\hline \multirow[b]{2}{*}{ Variable } & \multicolumn{2}{|c|}{ Awareness (N=375) } \\
\hline & $\begin{array}{c}\text { No } \\
\text { No. }(\%)\end{array}$ & $\begin{array}{c}\text { Yes } \\
\text { No. }(\%)\end{array}$ \\
\hline $\begin{array}{l}\text { Are you familiar with the term of } \\
\text { (patients' rights)? }\end{array}$ & $94(25.1)$ & $281(74.9)$ \\
\hline $\begin{array}{l}\text { Did you see a post of the patients' } \\
\text { rights in the hospital? }(\mathrm{n}=345)+\end{array}$ & $327(94.8)$ & $18(5.2)$ \\
\hline \multicolumn{3}{|c|}{ Do you know that the patient has the following rights? } \\
\hline $\begin{array}{l}\text { The physician should present } \\
\text { himself to you }\end{array}$ & $220(58.7)$ & $155(41.3)$ \\
\hline $\begin{array}{l}\text { The physician should respect the } \\
\text { patient's privacy }\end{array}$ & $40(10.7)$ & $335(89.3)$ \\
\hline $\begin{array}{l}\text { The physician should give you } \\
\text { chance to explain your complain }\end{array}$ & $40(10.7)$ & $335(89.3)$ \\
\hline $\begin{array}{l}\text { The physician should explain } \\
\text { patient condition in an easy } \\
\text { language }\end{array}$ & $50(13.3)$ & $325(86.7)$ \\
\hline $\begin{array}{l}\text { The physician should tell you } \\
\text { different ways of treatment }\end{array}$ & $93(24.8)$ & $282(75.2)$ \\
\hline $\begin{array}{l}\text { The physician should deal in a } \\
\text { good manner with you }\end{array}$ & $38(10.1)$ & $337(89.9)$ \\
\hline $\begin{array}{l}\text { Confidentiality of the patient } \\
\text { condition }\end{array}$ & $70(18.7)$ & $305(81.3)$ \\
\hline To obtain a copy of his file & $144(38.4)$ & $231(61.6)$ \\
\hline Optional participation in research & $113(30.1)$ & $262(69.9)$ \\
\hline $\begin{array}{l}\text { Give an informed consent before } \\
\text { any intervention }\end{array}$ & $50(13.3)$ & $325(86.7)$ \\
\hline To Know the cost of treatments & $55(14.7)$ & $320(85.3)$ \\
\hline $\begin{array}{l}\text { To have emergency care without } \\
\text { paying first. }\end{array}$ & $67(17.9)$ & $308(82.1)$ \\
\hline $\begin{array}{l}\text { To complain for any problem to the } \\
\text { manager }\end{array}$ & $73(19.5)$ & $302(80.5)$ \\
\hline $\begin{array}{l}\text { To be transferred after making } \\
\text { sure of availability of places and } \\
\text { care (referral protocol ) }\end{array}$ & $104(27.7)$ & $271(72.3)$ \\
\hline To have a discharge summary & $51(13.6)$ & $324(86.4)$ \\
\hline
\end{tabular}

$\$ \rightarrow$ thirty illiterate guardians were excluded from this question. 
Table (4): Relation between the awareness of the child guardians about the patients' rights and their residence.

\begin{tabular}{|c|c|c|c|c|c|}
\hline \multirow{2}{*}{\multicolumn{2}{|c|}{ Variable }} & \multirow{3}{*}{$\begin{array}{c}\begin{array}{c}\text { Rural } \\
\mathbf{N}=\mathbf{2 8 3}\end{array} \\
\text { No. }(\%) \\
73(25.6) \\
210(74.5)\end{array}$} & \multirow{3}{*}{$\begin{array}{c}\begin{array}{c}\text { Urban } \\
\text { N=92 }\end{array} \\
\text { No. (\%) } \\
21(22.8) \\
71(77.2)\end{array}$} & \multirow{3}{*}{$\chi^{2}$} & \multirow{3}{*}{$\begin{array}{c}\mathbf{P} \\
0.56\end{array}$} \\
\hline & & & & & \\
\hline $\begin{array}{l}\text { Are you familiar with the term of } \\
\text { (patients' rights)? }\end{array}$ & $\begin{array}{l}\text { No } \\
\text { Yes }\end{array}$ & & & & \\
\hline $\begin{array}{l}\text { Did you see a post of the patients' } \\
\text { rights in the hospital? }(\mathrm{n}=345)+\end{array}$ & $\begin{array}{l}\text { No } \\
\text { Yes }\end{array}$ & $\begin{array}{l}250(98.8) \\
3(1.2)\end{array}$ & $\begin{array}{l}77(83.7) \\
15(16.3)\end{array}$ & 31.2 & $<0.001 *$ \\
\hline Do you know that the patient has th & follow & rights? & & & \\
\hline Physician presents himself to you & $\begin{array}{l}\text { No } \\
\text { Yes }\end{array}$ & $\begin{array}{l}164(58.0) \\
119(42.0)\end{array}$ & $\begin{array}{l}56(60.9) \\
36(39.1)\end{array}$ & 0.24 & 0.62 \\
\hline Respect privacy & $\begin{array}{l}\text { No } \\
\text { Yes }\end{array}$ & $\begin{array}{c}33(11.7) \\
250(88.3)\end{array}$ & $\begin{array}{c}7(7.6) \\
85(92.4)\end{array}$ & 1.20 & 0.27 \\
\hline Chance to explain your complain & $\begin{array}{l}\text { No } \\
\text { Yes }\end{array}$ & $\begin{array}{c}31(11.0) \\
252(89.0)\end{array}$ & $\begin{array}{c}9(9.8) \\
83(90.2)\end{array}$ & 0.10 & 0.75 \\
\hline $\begin{array}{l}\text { Explain patient condition in easy } \\
\text { language }\end{array}$ & $\begin{array}{l}\text { No } \\
\text { Yes }\end{array}$ & $\begin{array}{l}37(13.1) \\
246(86.9)\end{array}$ & $\begin{array}{l}13(14.1) \\
79(85.9)\end{array}$ & 0.07 & 0.80 \\
\hline Choice of treatments & $\begin{array}{l}\text { No } \\
\text { Yes }\end{array}$ & $\begin{array}{l}71(25.1) \\
212(74.9)\end{array}$ & $\begin{array}{l}22(23.9) \\
70(76.1)\end{array}$ & 0.05 & 0.82 \\
\hline Dealing in good manner with you & $\begin{array}{l}\text { No } \\
\text { Yes }\end{array}$ & $\begin{array}{c}27(9.5) \\
256(90.5)\end{array}$ & $\begin{array}{l}11(12.0) \\
81(88.0)\end{array}$ & 0.45 & 0.51 \\
\hline Confidentiality & $\begin{array}{l}\text { No } \\
\text { Yes }\end{array}$ & $\begin{array}{c}55(19.4) \\
228(80.6)\end{array}$ & $\begin{array}{l}15(16.3) \\
77(83.7)\end{array}$ & 0.45 & 0.50 \\
\hline Copy of your files & $\begin{array}{l}\text { No } \\
\text { Yes }\end{array}$ & $\begin{array}{l}117(41.3) \\
166(58.7)\end{array}$ & $\begin{array}{l}27(29.4) \\
65(70.7)\end{array}$ & 4.22 & $0.04 *$ \\
\hline Optional participation in research & $\begin{array}{l}\text { No } \\
\text { Yes }\end{array}$ & $\begin{array}{l}87(30.7) \\
196(69.3)\end{array}$ & $\begin{array}{l}26(28.3) \\
66(71.7)\end{array}$ & 0.20 & 0.65 \\
\hline Informed consent & $\begin{array}{l}\text { No } \\
\text { Yes }\end{array}$ & $\begin{array}{l}36(12.7) \\
247(87.3)\end{array}$ & $\begin{array}{l}14(15.2) \\
78(84.8)\end{array}$ & 0.37 & 0.54 \\
\hline Know cost of treatments & $\begin{array}{l}\text { No } \\
\text { Yes }\end{array}$ & $\begin{array}{l}45(15.9) \\
238(84.1)\end{array}$ & $\begin{array}{l}10(10.9) \\
82(89.1)\end{array}$ & 1.40 & 0.24 \\
\hline Emergency care without paying first. & $\begin{array}{l}\text { No } \\
\text { Yes }\end{array}$ & $\begin{array}{c}59(20.9) \\
224(79.1)\end{array}$ & $\begin{array}{c}8(8.7) \\
84(91.3)\end{array}$ & 6.99 & $0.01 *$ \\
\hline Complain in any problem & $\begin{array}{l}\text { No } \\
\text { Yes }\end{array}$ & $\begin{array}{c}58(20.5) \\
225(79.5)\end{array}$ & $\begin{array}{l}15(16.3) \\
77(83.7)\end{array}$ & 0768 & 0.38 \\
\hline Referral protocol & $\begin{array}{l}\text { No } \\
\text { Yes }\end{array}$ & $\begin{array}{c}85(30.0) \\
198(70.0)\end{array}$ & $\begin{array}{l}19(20.7) \\
73(79.4)\end{array}$ & 3.05 & 0.08 \\
\hline Discharge summary & $\begin{array}{l}\text { No } \\
\text { Yes }\end{array}$ & $\begin{array}{l}42(14.8) \\
241(85.2)\end{array}$ & $\begin{array}{c}9(9.8) \\
83(90.2)\end{array}$ & 1.51 & 0.22 \\
\hline
\end{tabular}

* Statistically significant

$\ddagger \rightarrow$ thirty illiterate guardians were excluded from this question 
Table (5): Relation between the awareness of the child guardians about the patients' rights and the age of the sick child.

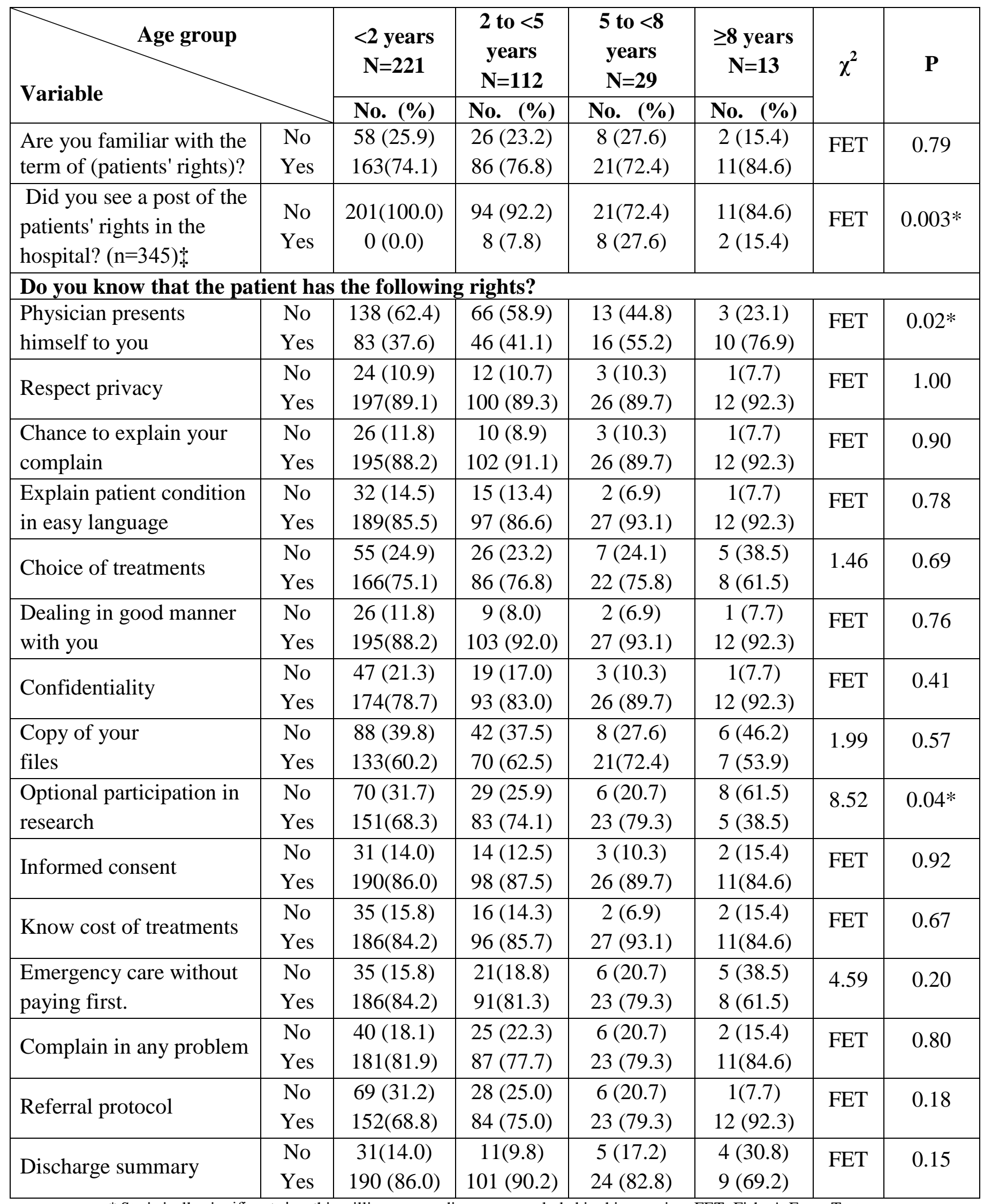


Table (6): Relation between the awareness of the child guardians about the patients' rights and their educational level.

\begin{tabular}{|c|c|c|c|c|c|c|c|}
\hline \multirow{2}{*}{\multicolumn{2}{|c|}{ Variable }} & $\begin{array}{c}\text { Illiterate/read } \\
\text { and write } \\
\mathrm{N}=45\end{array}$ & $\begin{array}{c}\text { Basic } \\
\text { education } \\
\mathbf{N}=130 \\
\end{array}$ & $\begin{array}{l}\text { Secondary } \\
\quad \mathrm{N}=167\end{array}$ & $\begin{array}{l}\text { University } \\
\qquad \mathbf{N}=\mathbf{3 3}\end{array}$ & \multirow{3}{*}{$\begin{array}{c}\chi^{2} \\
\text { FET }\end{array}$} & \multirow{3}{*}{$\begin{array}{c}\mathbf{P} \\
<0.001^{*}\end{array}$} \\
\hline & & No. $(\%)$ & No. $(\%)$ & No. $(\%)$ & No. $(\%)$ & & \\
\hline $\begin{array}{l}\text { Are you familiar with } \\
\text { the term of (patients' } \\
\text { rights)? }\end{array}$ & $\begin{array}{l}\text { No } \\
\text { Yes }\end{array}$ & $\begin{array}{l}26(57.8) \\
19(42.2)\end{array}$ & $\begin{array}{l}38(29.2) \\
92(70.8)\end{array}$ & $\begin{array}{l}29(17.4) \\
138(82.6)\end{array}$ & $\begin{array}{c}1(3.0) \\
32(97.0)\end{array}$ & & \\
\hline $\begin{array}{l}\text { Did you see a post of } \\
\text { the patients' rights in } \\
\text { the hospital? }(n=345)\end{array}$ & $\begin{array}{l}\text { No } \\
\text { Yes }\end{array}$ & $\begin{array}{c}14(93.3) \\
1(6.7)\end{array}$ & $\begin{array}{c}126(96.9) \\
4(3.1)\end{array}$ & $\begin{array}{c}158(94.6) \\
9(5.4)\end{array}$ & $\begin{array}{l}29(87.9) \\
4(12.1)\end{array}$ & FET & 0.21 \\
\hline Do you know that the & tient & s the following ri & & & & & \\
\hline $\begin{array}{l}\text { Physician presents } \\
\text { himself to you }\end{array}$ & $\begin{array}{l}\text { No } \\
\text { Yes }\end{array}$ & $\begin{array}{l}29(64.4) \\
16(35.6)\end{array}$ & $\begin{array}{l}80(61.5) \\
50(38.5)\end{array}$ & $\begin{array}{c}100(59.9) \\
67(40.1)\end{array}$ & $\begin{array}{l}11(33.3) \\
22(66.7)\end{array}$ & 9.90 & $0.02 *$ \\
\hline Respect privacy & $\begin{array}{l}\text { No } \\
\text { Yes }\end{array}$ & $\begin{array}{l}12(26.7) \\
33(73.3)\end{array}$ & $\begin{array}{c}15(11.5) \\
115(88.5)\end{array}$ & $\begin{array}{c}12(7.2) \\
155(92.8)\end{array}$ & $\begin{array}{c}1(3.0) \\
32(97.0)\end{array}$ & 16.34 & $0.001 *$ \\
\hline $\begin{array}{l}\text { Chance to explain your } \\
\text { complain }\end{array}$ & $\begin{array}{l}\text { No } \\
\text { Yes }\end{array}$ & $\begin{array}{l}11(24.4) \\
34(75.6)\end{array}$ & $\begin{array}{c}14(10.8) \\
116(89.2)\end{array}$ & $\begin{array}{c}14(8.4) \\
153(91.6)\end{array}$ & $\begin{array}{c}1(3.0) \\
32(97.0)\end{array}$ & FET & $0.01 *$ \\
\hline $\begin{array}{l}\text { Explain patient } \\
\text { condition in easy } \\
\text { language }\end{array}$ & $\begin{array}{l}\text { No } \\
\text { Yes }\end{array}$ & $\begin{array}{l}11(24.4) \\
34(75.6)\end{array}$ & $\begin{array}{l}20(15.4) \\
110(84.6)\end{array}$ & $\begin{array}{c}18(10.8) \\
149(89.2)\end{array}$ & $\begin{array}{c}1(3.0) \\
32(97.0)\end{array}$ & FET & $0.03 *$ \\
\hline Choice of treatments & $\begin{array}{l}\text { No } \\
\text { Yes }\end{array}$ & $\begin{array}{l}18(40.0) \\
27(60.0)\end{array}$ & $\begin{array}{c}30(23.1) \\
100(76.9)\end{array}$ & $\begin{array}{c}38(22.8) \\
129(77.3)\end{array}$ & $\begin{array}{c}7(21.2) \\
26(78.8)\end{array}$ & 6.38 & 0.09 \\
\hline $\begin{array}{l}\text { Dealing in good } \\
\text { manner with you }\end{array}$ & $\begin{array}{l}\text { No } \\
\text { Yes }\end{array}$ & $\begin{array}{l}11(24.4) \\
34(75.6)\end{array}$ & $\begin{array}{c}15(11.5) \\
115(88.5)\end{array}$ & $\begin{array}{c}10(6.0) \\
157(94.0) \\
\end{array}$ & $\begin{array}{c}2(6.1) \\
31(93.9)\end{array}$ & FET & $0.005^{*}$ \\
\hline Confidentiality & $\begin{array}{l}\text { No } \\
\text { Yes }\end{array}$ & $\begin{array}{l}18(40.0) \\
27(60.0)\end{array}$ & $\begin{array}{c}27(20.8) \\
103(79.2)\end{array}$ & $\begin{array}{c}23(13.8) \\
144(86.2)\end{array}$ & $\begin{array}{c}2(6.1) \\
31(93.9)\end{array}$ & FET & $<0.001 *$ \\
\hline $\begin{array}{l}\text { Copy of your } \\
\text { files }\end{array}$ & $\begin{array}{l}\text { No } \\
\text { Yes }\end{array}$ & $\begin{array}{l}26(57.8) \\
19(42.2)\end{array}$ & $\begin{array}{l}47(36.1) \\
83(63.8)\end{array}$ & $\begin{array}{c}62(37.1) \\
105(62.2)\end{array}$ & $\begin{array}{c}9(27.3) \\
24(72.7)\end{array}$ & 9.26 & $0.03 *$ \\
\hline $\begin{array}{l}\text { Optional participation } \\
\text { in research }\end{array}$ & $\begin{array}{l}\text { No } \\
\text { Yes }\end{array}$ & $\begin{array}{l}20(44.4) \\
25(55.6)\end{array}$ & $\begin{array}{l}37(28.5) \\
93(71.5)\end{array}$ & $\begin{array}{c}48(28.7) \\
119(71.3) \\
\end{array}$ & $\begin{array}{c}8(24.2) \\
25(75.8)\end{array}$ & 5.25 & 0.15 \\
\hline Informed consent & $\begin{array}{l}\text { No } \\
\text { Yes }\end{array}$ & $\begin{array}{l}13(28.9) \\
32(71.1)\end{array}$ & $\begin{array}{c}19(14.6) \\
111(85.4)\end{array}$ & $\begin{array}{c}17(10.2) \\
150(89.8)\end{array}$ & $\begin{array}{c}1(3.0) \\
32(97.0)\end{array}$ & FET & $0.004 *$ \\
\hline $\begin{array}{l}\text { Know cost of } \\
\text { treatments }\end{array}$ & $\begin{array}{l}\text { No } \\
\text { Yes }\end{array}$ & $\begin{array}{l}12(26.7) \\
33(73.3)\end{array}$ & $\begin{array}{c}27(20.8) \\
103(79.2)\end{array}$ & $\begin{array}{c}13(7.8) \\
154(92.2) \\
\end{array}$ & $\begin{array}{c}3(9.1) \\
30(90.9)\end{array}$ & FET & $0.001 *$ \\
\hline $\begin{array}{l}\text { Emergency care } \\
\text { without paying first. }\end{array}$ & $\begin{array}{l}\text { No } \\
\text { Yes }\end{array}$ & $\begin{array}{l}18(40.0) \\
27(60.0)\end{array}$ & $\begin{array}{c}25(19.2) \\
105(80.8)\end{array}$ & $\begin{array}{c}19(11.4) \\
148(88.6)\end{array}$ & $\begin{array}{c}5(15.2) \\
28(84.9)\end{array}$ & 20.14 & $<0.001 *$ \\
\hline $\begin{array}{l}\text { Complain in any } \\
\text { problem }\end{array}$ & $\begin{array}{l}\text { No } \\
\text { Yes }\end{array}$ & $\begin{array}{l}18(40.0) \\
27(60.0)\end{array}$ & $\begin{array}{c}26(20.0) \\
104(80.0)\end{array}$ & $\begin{array}{c}25(15.0) \\
142(85.0)\end{array}$ & $\begin{array}{c}4(12.1) \\
29(87.9)\end{array}$ & FET & $0.003 *$ \\
\hline Referral protocol & $\begin{array}{l}\text { No } \\
\text { Yes }\end{array}$ & $\begin{array}{l}19(42.2) \\
26(57.8)\end{array}$ & $\begin{array}{l}37(28.5) \\
93(71.5)\end{array}$ & $\begin{array}{c}41(24.6) \\
126(75.5)\end{array}$ & $\begin{array}{c}7(21.1) \\
26(78.8)\end{array}$ & 6.29 & 0.10 \\
\hline Discharge summary & $\begin{array}{l}\text { No } \\
\text { Yes }\end{array}$ & $\begin{array}{l}15(33.3) \\
30(66.7)\end{array}$ & $\begin{array}{c}15(11.5) \\
115(88.5)\end{array}$ & $\begin{array}{c}18(10.8) \\
149(89.2)\end{array}$ & $\begin{array}{c}3(9.1) \\
30(90.9)\end{array}$ & FET & $0.003^{*}$ \\
\hline
\end{tabular}

$+\rightarrow$ thirty illiterate guardians were excluded in this question,

FET=Fisher's Exact Test 